Acta Regionalia et Environmentalica 1

Nitra, Slovaca Universitas Agriculturae Nitriae, 2015, pp. 6-10

\title{
LOCATION ON NATURAL VALUABLE AREAS AS A CONDITION FOR THE DEVELOPMENT OF ENTERPRISES BASED ON THE USE OF NATURAL RESOURCES - THE LUBLIN VOIVODESHIP (POLAND)
}

\author{
Magdalena ZWOLIŃSKA-LIGAJ \\ Pope John Paul II State School of Higher Education in Biala Podlaska, Poland
}

The aim of the study is to identify opportunities and constraints of the development of companies whose business is based on the exploitation of natural resources resulting from their location in areas of natural value. The study area consisted of 40 municipalities. Five companies were selected for the study in each municipality. The study used the method of diagnostic survey using a questionnaire interview. The results obtained give rise to a finding that economic activity based on the use of local natural resources, taking into account the need to protect the natural environment, is a legitimate direction and an opportunity for the development of local economies of areas of natural value. However, given the limitations of economic activities in natural valuable areas, it requires support, mainly with information and finance. The most important limitations of economic activities in natural valuable areas include the lack of preferential financial instruments, difficulties of the investment process and the lack of financial compensation for profits lost due to the location.

Keywords: entrepreneurship, valuable natural areas

Protected areas fulfil many roles and functions that stray away from the traditional paradigm of environmental protection. These include: protection and enhancement of biodiversity (a regulatory function), regional and supra-regional social effects (habitat functions), keeping the gene pool and the prevention of natural disasters (support functions), sustainable development of the region (a developmental function) and environmental education and training (an informative function) (Mose and Weixlbaumer, 2007).

The modern conception of the protective functions of the protected areas is based on treating them as elements of sustainability/sustainable development (Bishop, Phillips, Warren 1995). The tendency to widely include the protected areas into economic areas and gradually eliminate restrictions on local entrepreneurship is increasing (Boltromiuk, 2003).

Within the natural valuable areas, management efficiency, recognizing the leading role of natural assets and the need for comprehensive protection requires above all developing economic functions genetically related to the environment. However, it must be done within the scope and in a way that ensures sustainability of the implementation of these functions (Dobrzański 2000). Natural resources of the valuable areas could become the basis for the development of various fields of business. The protected areas possible for implementation primarily include:organicfarming, including organic food production, medicinal plants, honey and beekeeping materials; qualified tourism - ecotourism and rural tourism; healthcare - including sanatorium treatment and limited forest management (Kulczyk-Dynowska, 2013).
One of the comprehensive classifications of the activities related to the environment and the natural heritage differentiates the core, basic and dependent businesses. Core activities are related to the management, operation and / or promoting the use of environmental resources. This category includes, among others, the environmental sector activities involved in the provision of environmental goods and services, market products and environmental services, e.g. tourism based on natural resources. The group of core businesses relates to the operation and management of the environment and involves the extraction of natural resources, agriculture, mining and forestry. The activities are dependent and those that depend on the environment in the commercial dimension but are not directly involved in the management of resources. Examples of such activities are: leisure tourism, recreation and production, in which the environment is inextricably embedded in the local product (Courtney et al., 2006).

The aim of the study is to identify the opportunities and constraints of the development of companies whose businesses are based on the exploitation of the natural resources, as resulting from their location in natural valuable areas. In this study, we hypothesized that, in the face of the generally difficult conditions for entrepreneurship development that the natural valuable areas create for them, entrepreneurs from the industries using the resources and the values of the environment recognize and utilize the greater opportunities arising from their location, as compared with those of other sectors. 


\section{Material and methods}

The survey covered 40 rural and semi-urban areas of the Lublin province (about $20 \%$ of all communes), including 30 of the most ecologically precious and 10 comparative communes from the group of communes with low natural values. The natural values of the communes of the Lublin voivodeship were determined on the basis of the test results by Guzal-Dec (2013).

In each of the communes, on the basis of REGON, 5 companies were selected for the study, following the reflection of the sectoral structure of economic entities in the community and nominating test subjects with the highest level of employment. The study used the method of a diagnostic survey using a questionnaire interview. The interviews with owners (or managers) of the companies were realized in November-December of 2013.

In the group of 200 companies, 111 business entities were distinguished, based on the use of natural resources (Table 1). The group included entities in which natural conditions determined the possibilities of doing business and offering specific types of products / services.

The enterprises based on the natural resources in the areas of natural value were represented primarily by manufacturing (30.6\%), activities related to the accommodation and food services $(27.1 \%)$ and agriculture, forestry, hunting and fishing (23.5\%). In the case of other communes, in the structure of enterprises based on resources, the dominant sector was manufacturing (57.7\%). Other entities represented primarily their commercial activities - on both types of areas. The group of the subjects studied was dominated by micro-enterprises.

The paper presents comparative characteristics of the entities representing the industries based on the exploitation of natural resources, as compared with other ecologically valuable communes and others. The adopted
Table 1 Enterprises using natural resources and others by location in ecologically valuable and other communes

\begin{tabular}{|l||c|c|c|}
\hline \multicolumn{1}{|l||}{$\begin{array}{l}\text { Type of } \\
\text { enterprise }\end{array}$} & \multicolumn{3}{|c|}{ Type of communes } \\
\cline { 2 - 4 } & $\begin{array}{c}\text { natural valuable } \\
\text { communes }\end{array}$ & $\begin{array}{c}\text { other } \\
\text { communes }\end{array}$ & total \\
\hline \hline $\begin{array}{l}\text { Using natural } \\
\text { resources }\end{array}$ & 85 & 26 & 111 \\
\hline Other & 65 & 24 & 89 \\
\hline Total & 150 & 50 & 200 \\
\hline \multicolumn{4}{|c|}{ Source: author's construction based on the research }
\end{tabular}

analytical system allowed the identification of the impact of the location of the entity in the area more or less valuable in terms of ecological conditions on the opinions on the conditions of the development of enterprises. The results of the study were presented in a descriptive and graphic form of tables and graphs.

The development was prepared within the framework of the research project No. 2011/01/D/HS4/03927 entitled "Environmental Conditions and Factors of the Development of Economic Functions on the Natural Valuable Areas of the Lublin Voivodeship" funded by the National Science Centre.

\section{Results and discussion}

For the majority $(57.0 \%)$ of the entities using the resources of the local environment, operating on ecologically valuable areas, using the range of opportunities was declared to run and develop economic activity resulting from that particular location. In the group of entities not based on natural resources of the commune, vast majority of businesses (82.0\%) declared the lack of the use of such opportunities (Figure 1).

Exploitation of the opportunities arising from access to resources and the natural assets of communes in relation to areas not distinguished by a high degree of ecological values

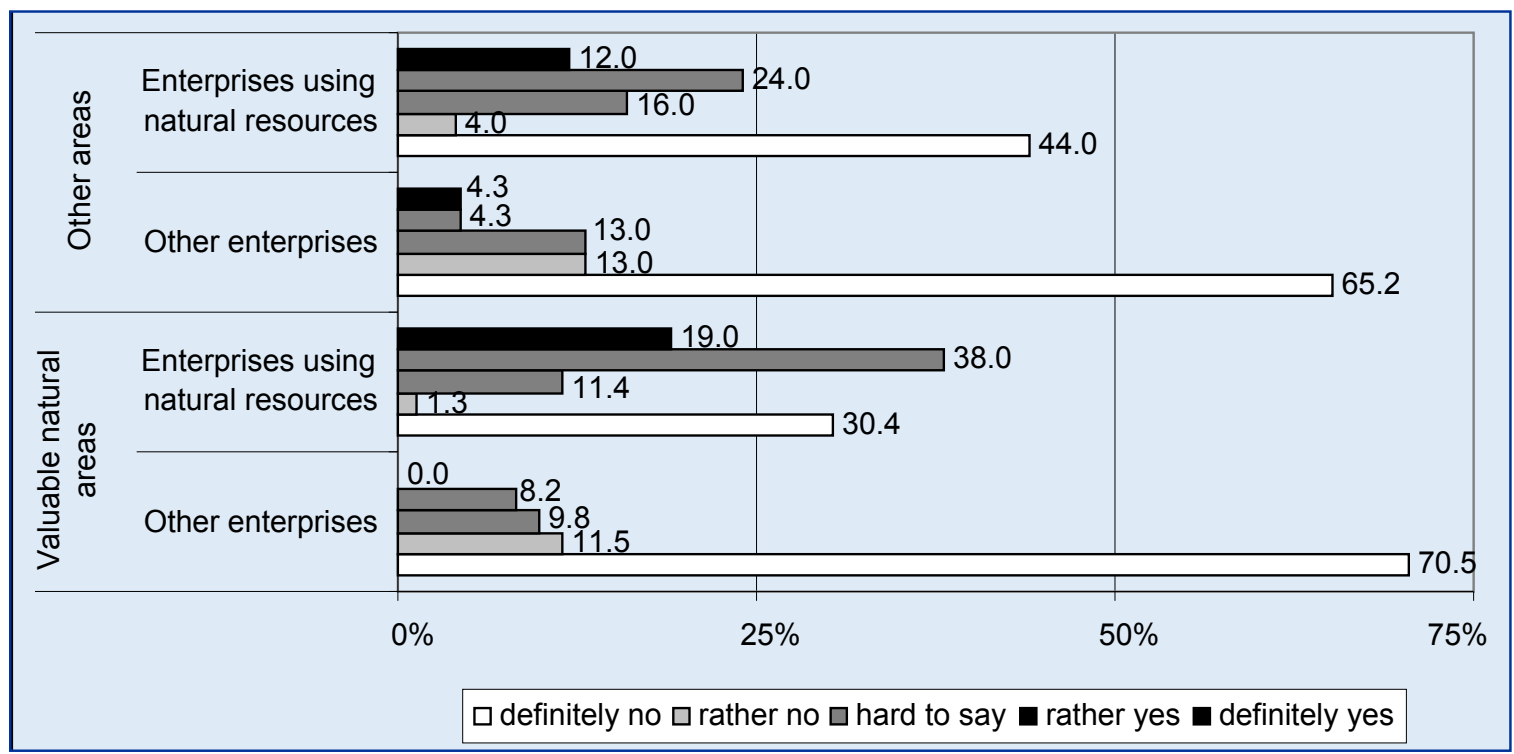

Figure 1 Assessment whether the enterprise uses a chance to run and develop economic activity arising from the location in the commune of valuable natural assets and resulting from access to resources and natural assets of the commune (other areas)

Source: own development 


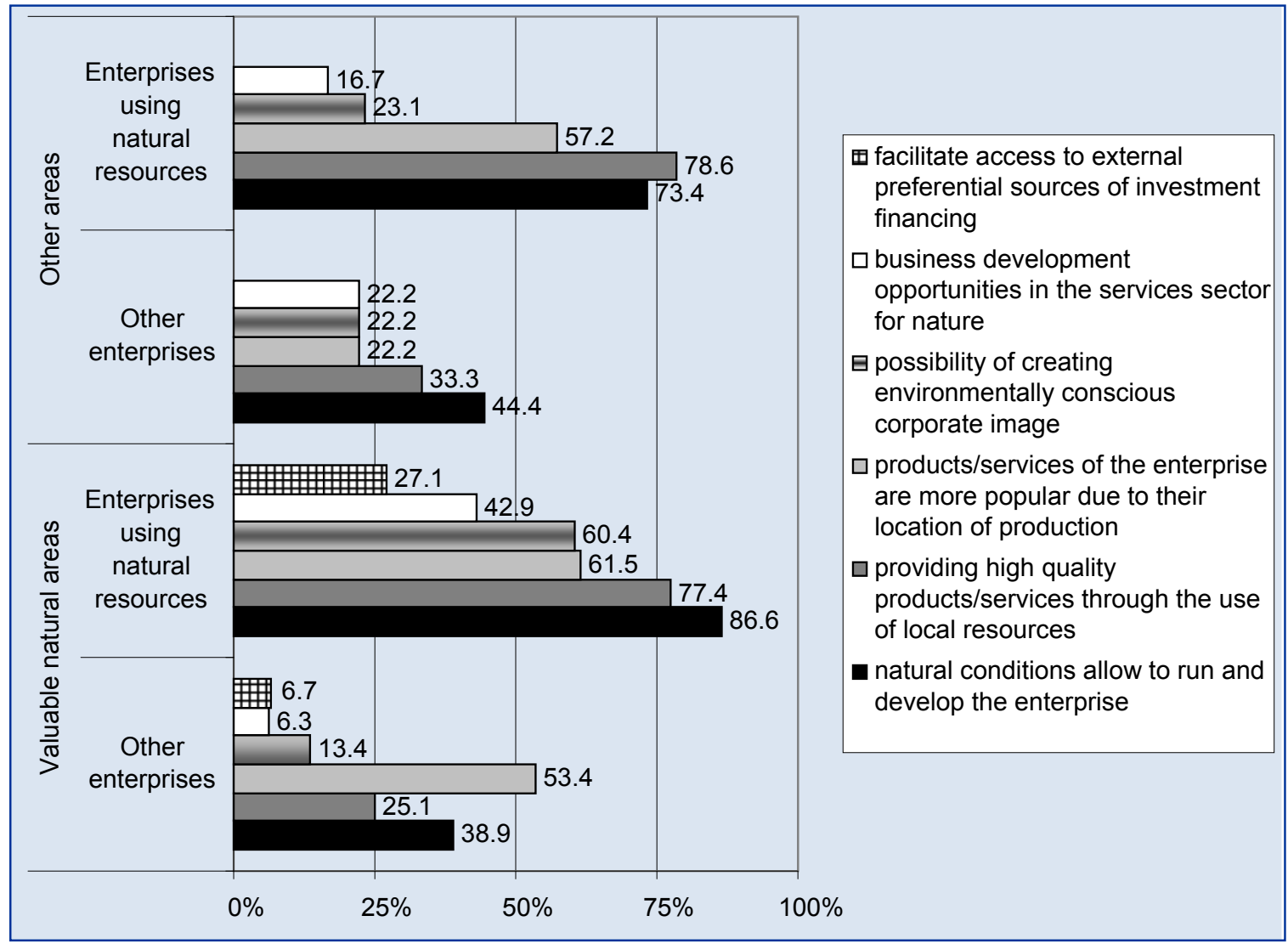

Figure 2 The opportunities perceived for enterprises based on natural resources resulting from the location of the access to resources and natural assets of the communes and perceived by other companies arising out of the access to resources and natural assets of the communes

Source: author's construction based on the research

is smaller, in accordance with the declarations of enterprises. These observations seem to indicate the existence of the areas of influence of the unique characteristics of the natural environment on the development opportunities of entities based on their use in their operations (Figure 1).

The owners (managers) of the entities based on a variety of natural resource perceived the opportunities arising from the location of the company in the areas of natural value. For almost all of the entities $(86.6 \%)$, natural conditions were the condition of the entity existence and the primary determinant of its development. In particular, according to the respondents, the majority of local ecological conditions allowed the entities to provide high quality products / services $(77.4 \%)$ and the location of their creation was what made them enjoy greater interest of clients (61.5\%). More than half $(60.4 \%)$ of the enterprises operating in the environmentally valuable areas could see the opportunities arising from the possibility of creating the environmentally friendly image of the company. The entities rarely perceived business opportunities in the service sector for nature and the existence of facilities for access to concessional financing sources. In the case of other communes, the assessed opportunities were less-perceived (Figure 2).

Entrepreneurs not basing their activities on the resources and activities of the environmental values of the communes much less perceived the opportunities arising from the access to natural assets and resources of the communes. Among the entities located in the most environmentally valuable areas, it was indicated that the location of the production of products / services has a positive effect on customer interest (53.4\% of responses) and that natural conditions allow them to run and develop activities (38.9\%). In other communes, entrepreneurs stressed the overall impact of natural conditions on enterprises (44.4\%) and the ability to provide high quality products (33.3\%) (Figure 2).

The most frequently reported restrictions of the operations of the entrepreneurs conditioned by the need to protect the environment of the natural valuable locations included the lack of preferential financial instruments for investors, the lack of financial compensation for lost benefits for the self-employed and obstructions or restrictions of the investment process. The scale of the perceived limitations, however, was not significant (Figure 3).

The functioning of the valuable natural areas is associated with reduced running and development of economic activities to a greater extent in relation to the entities not basing their activities on the assets and resources of the natural environment. The entrepreneurs more frequently reported, as compared to those operating in the resource-based industries, such restrictions on their activities as the lack of financial compensation for the lost profits for conducting economic activity (a difference of 11.5 percentage points - pp), lack of ideas, knowledge about the potential development of entrepreneurship in basing on the values of the natural environment and resources of the commune (10.8 pp), lack of opportunities 
for cooperation and exchange of experiences with other entities from valuable natural areas (6.4 pp), reducing the area for investment development (4.6 pp), or the lack of preferential financial instruments for investors (2.6 pp).

Within the other communes, difficulties were reported more often in the case of the entities using natural resources. They were related to: the lack of financial compensation for lost profits for the self-employed, the limited area for investment development and difficulties in the investment process.

Entrepreneurs from both groups perceived the most common limitations as associated with the lack of financial support (no preferential financial instruments, lack of financial compensation for loss of profits) and the investment difficulties. Somewhat less frequently the limitations resulting from the lack of knowledge about the conditions and how to adapt business to the requirements of the environment protection were indicated, along with the business development opportunities based on the values of the natural environment and resources of the municipality or due to the lack of opportunities for cooperation and exchange of experiences with other entrepreneurs. In addition, the surveyed entrepreneurs very rarely perceived threat in the form of potential conflicts between the given entity and the local community.
These results are consistent with the results of the opinions (Czarnecki, 2011) of the entrepreneurs on the conditions of business operations within the areas covered by the Natura 2000 network, from which it follows that the potential benefits of Natura 2000 were indicated mainly by the business owners forming the broad tourism environment, using the resources and values of the natural environment. Limitations of the enterprise development arising from the location were mainly perceived by the representatives of industries dependent on access to the area and supply of natural resources. Other studies (Dokument zamykający..., 2012) conducted in the areas of high natural value also suggest that the entrepreneurs basing their economic activities on the natural values of their region tend to have a positive opinion on the conditions of doing business. Negative opinions on doing business in the areas of natural value were highlighted among the entrepreneurs from other sectors whose activities were not to use the advantages of the landscape.

In light of the perceived development limitations, there emerges a need to design effective forms of assistance to companies within valuable natural areas, in particular those basing their activities on environmental resources. Similar conclusions can be drawn from the study of

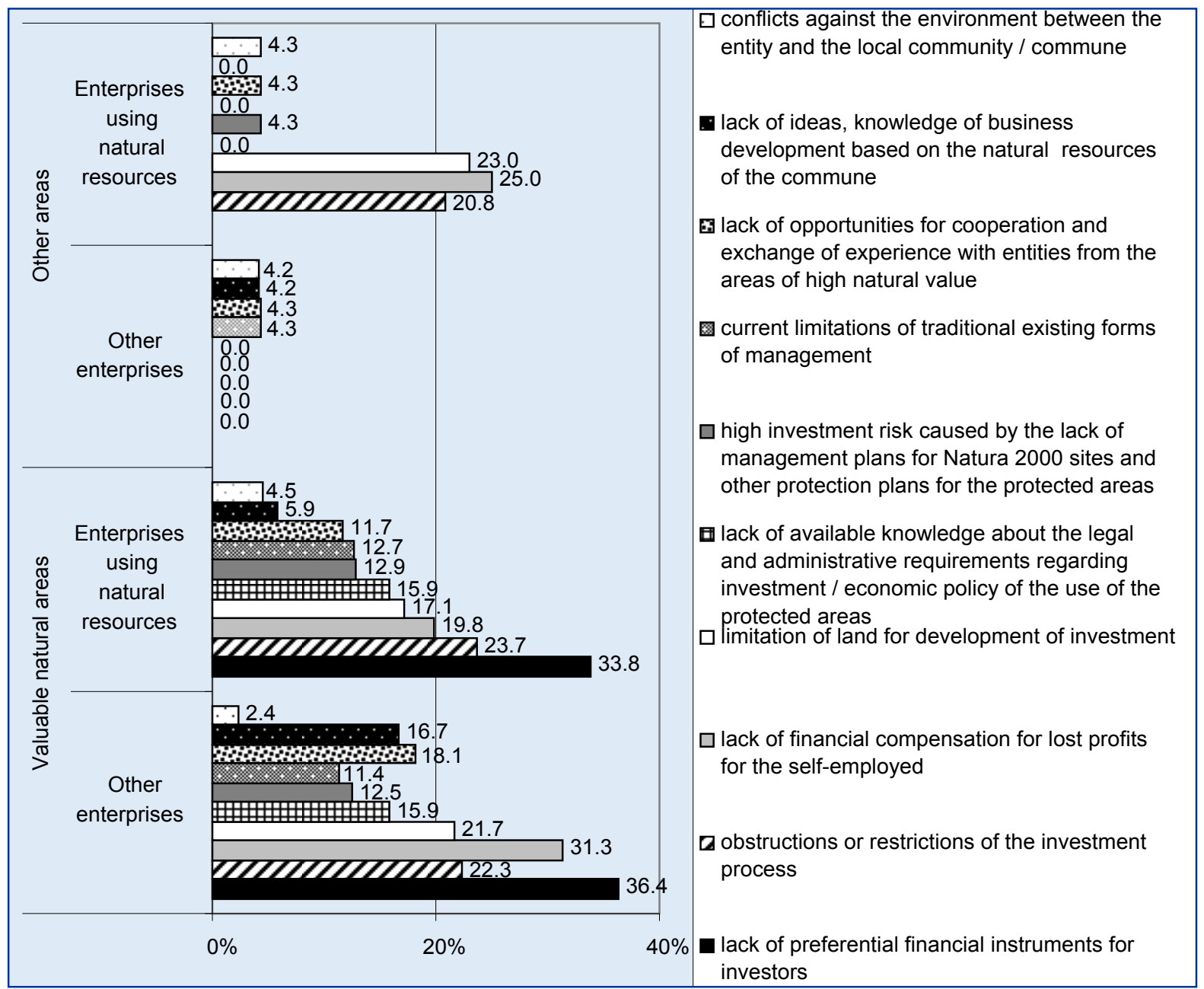

Figure 3 Limitations to run and develop economic activity resulting from the need to protect the environment of the commune, as perceived by the entities using natural resources and others

Source: author's construction based on the research 
entrepreneurs operating within the Natura 2000 network (Analiza uwarunkowań..., 2012). They revealed an important role of: information and promotional support, grants and subsidies, advice of business environment institutions, using exemptions and tax credits.

\section{Conclusions}

The results obtained allow the conclusion that economic activity based on the use of local natural resources and meeting the requirements of the environmental protection is a legitimate direction and opportunity for the development of local economies on valuable natural areas. Valuable natural areas, as compared to others, create difficult conditions for the development of enterprises. In the case of industries that use natural resources, we can, however, observe the presence of favourable location factors enhancing their market competitiveness. Thus, the hypothesis formulated in this study has been positively verified.

The entrepreneurs using natural resources recognize and exploit particular opportunities arising from their location within valuable natural areas. These include the ability to provide high quality products / services whose location of production makes them more interesting to customers, the opportunity to create environmentally friendly corporate images. In addition, these entities, to a lesser extent, relate to operating restrictions arising from their location within natural valuable areas.

However, given the limitations of the economic activities within environmentally valuable areas, resulting from the need to protect the natural environment, they require support, mainly with respect to information and finance. The major limitations of economic activities in environmentally valuable areas include: the lack of preferential financial instruments, obstruction of the investment process and the lack of financial compensation for lost profits arising from the location.

The results of studies (Dokument zamykający..., 2012) conducted in different regions of the European Union also show that the natural environment is one of the favourable factors affecting the conduct of diversified operations but regional policy is not always sufficiently targeted to support the activities. The distance from large regional, national or international markets, combined with the small size of the local markets creates a competitive disadvantage for businesses. Access to business support, in conjunction with financial capacity, is limited. A great obstacle to the development of entrepreneurship is the lack of knowledge about development opportunities. Respondents showed great interest in issues related to investment opportunities.

An important instrument to support operations based on the resources and wealth of ecologically valuable areas is to identify the possible areas of the economy to be developed, examples of companies that have been successfully functioning in similar conditions. The following should be stressed: the role of the popularization of the experience of other countries, presenting possible model solutions to be implemented, presenting conditions of the activities of such companies, including restrictions that occur, their effects, how to troubleshoot, the institutional, legal and financial support and tangible results. It is necessary to create an effective system of institutional and financial support for such projects (Czarnecki, 2011).
An emerging area of further study of nature sites in the studied region is selective, individual approach to each of the nature sites, taking into account the existing conditions in the area with respect to the social, economic and natural heritage, including the form of nature conservation. Followed by gathering the views of the economic and social environment on the conditions, needs and capacity of building and developing specific strategies to exploit the opportunities for local economies being inherent in the specifics of the resources and values of the natural environment and overcoming limitations.

\section{Acknowledgment}

This paper was prepared within the framework of the research project No. 2011/01/D/HS4/03927 entitled "Environmental Conditions and Factors of Economic Functions Development in Valuable Natural Areas of the Lublin Voivodeship" funded by the National Science Centre.

\section{References}

ANALIZA uwarunkowań prowadzenia działalności gospodarczej na obszarach Natura 2000 w województwie warmińsko-mazurskim, Dokument opracowany w ramach projektu "Business to Nature Interregional Approach to SMEs and Entrepreneurship in Natural Areas", współfinansowanego z Programu INTERREG IVC.2012. [online]. Warszawa : Warmińsko-Mazurska Agencja Rozwoju Regionalnego S.A. w Olsztynie, p. 83. [Retrieved 2014-09-18]. Retrieved from: http://www.business2nature.eu/files/Analiza_ uwarunkowan_Natura_2000_woj_warminsko-mazurskie.pdf

BISHOP, K. - PHILLIPS, A. - WARREN, L. 1995. Protected for ever? Factors shaping the future of protected areas Policy. In Land Use Policy, vol. 12, 1995, no. 4, p. 304.

BOŁTROMIUK, A. 2003. Ekonomiczne aspekty funkcjonowania obszarów chronionych. Białystok : Wyd. Uniwersytetu w Białymstoku, 2003. pp. 88-89. ISBN 8389031655.

COURTNEY, P. - HILL, G. - ROBERTS, D. 2006. The role of natural heritage in rural development: An analysis of economic linkages in Scotland. In Journal of Rural Studies, 2006, no. 22, pp. 470-471.

CZARNECKI, A. 2011. Perspektywy rozwoju obszarów wiejskich objętych siecią Natura 2000 w opinii lokalnych przedsiębiorców. In BOŁTROMIUK, A. Uwarunkowania zrównoważonego rozwoju gmin objętych siecią Natura 2000. Warszawa :IRWiR PAN, 2011. pp. 265266. ISBN 83-89900-38-6.

DOBRZAŃSKI, G. 2000. Trwały rozwój w ujęciu regionalnym i lokalnym. In Ekonomia i Środowisko, 2000, no. 2(17), pp. 27-28.

DOKUMENT zamykający projekt "Business to Nature - nowe podejście do rozwoju przedsiębiorczości na obszarach cennych przyrodniczo", Rekomendacje dla polityki, INTERREGIVC, European Regional Development Fund, 2012. [online] [Retrieved 201409-15]. Retrieved from: http://www.business2nature.eu/files/ B2N_final\%20document_PL.pdf

GUZAL-DEC, D. 2013. Operacjonalizacja modelu Presja-Stan-Reakcja w badaniu cenności ekologicznej gmin wiejskich na przykładzie województwa lubelskiego. In Rocznik Ochrony Środowiska/Annual Set the Environment Protection, vol. 15, 2013, no. 3, pp. 2925-2941. KULCZYK-DYNOWSKA, A. 2013. Rozwój regionalny na obszarach chronionych. Wrocław : Uniwersytet Przyrodniczy we Wrocławiu, 2013. p. 129. ISBN 9788377171608.

MOSE, I. - WEIXLBAUMER, N. 2007. A new paradigm for protected areas in Europe. In MOSE, I. Protected areas and regional development in Europe: towards a new model for the $21^{\text {st }}$ century. Aldershot : Ashgate, 2007, pp. 4-5. ISBN 9780754683254. 